grafting: meta-analysis. J Thorac Cardiovasc Surg 2016; 151: 60-77.e1-58.

4. Lamy A, Devereaux PJ, Prabhakaran D, et al. Offpump or on-pump coronary-artery bypass grafting at 30 days. N Engl J Med 2012; 366: 1489-97.

5. Marczin, Nandor, AND Raja, Shahzad G.. "Offpump coronary artery bypass grafting" AME Medical Journal [Online], Volume 5(24 March 2020)

6. Osawa H 89, Inaba H, Kinoshita O, Akashi O, et al, (2011), "Off-pump coronary artery bypass grafting with an aortic nonclamping technique may reduce the incidence of cerebral complications", General Thoracic and Cardiovascular Surgery, 59 (10), pp. 681.
7. Puskas JD, Mack MJ, Smith CR. On-pump versus offpump CABG. N Engl J Med 2010; 362, 851; author reply 853-4.

8. Shroyer AL, Grover FL, Hattler B, et al. Onpump versus off-pump coronary-artery bypass surgery. N Engl J Med 2009; 361: 1827-37.

9. Wijeysundera DN, Beattie WS, Djaiani G, et al. Off pump coronary artery surgery for reducing mortality and morbidity: meta-analysis of randomized and observational studies. J Am Coll Cardiol 2005; 46: 872-82. 21) Puskas JD, Thourani VH, Kilgo $P$, et al. Off-pump coronary artery bypass disproportionately benefits highrisk patients. Ann Thorac Surg 2009; 88: 1142-7.

\title{
ĐÁNH GIÁ TÌNH TRANG DI CĂN HẠCH CỔ VÀ MỐI TƯƠNG QUAN TỚI ĐẶC ĐIỂM BỆNH HỌC UNG THƯ KHOANG MIỆNG
}

\author{
Lê Văn Quảng1,2, Ngô Quốc Duy ${ }^{1}$, Lê Thế Đường ${ }^{1}$, Ngô Xuân Quý1
}

\section{TÓM TẮT}

Mục tiêu: Đánh giá tình trạng di căn hạch cổ và mối tương quan tới đặc điểm bệnh học ung thư khoang miệng. Phương pháp nghiên cứu: Gồm 158 BN chẩn đoán ung thư khoang miệng giai đoạn cT14N0-2M0 điều trị tại bệnh viện K từ 2017 - 2019. Kết quả: Tuổi trung bình là $56,1 \pm 10,1$ (25 - 83). Nam chiếm đa số $(73,4 \%)$. Tỷ lệ di căn hạch sau mổ là $32,9 \%$, trong đó di căn hạch tiềm ẩn là $21,5 \%$. Không có mối tương quan giữa tình trạng di căn hạch với tuổi và giới $(p>0,05)$. Tình tranng di căn hạch có mối tương quan chặt chẽ với kích thước u ( $p<0,001, C I$ 95\% $2,3-9,5)$ đô xâm lấn sâu ( $\mathrm{p}<0,001 ; \mathrm{CI} 95 \% \quad 2,7$ $14,9)$ và giai đoạn $T$ sau mổ $(p<0,001)$. Kết luận: Tình trạng di căn hạch cổ có mối tương quan chặt chẽ với kích thước u, độ xâm lấn sâu và giai đoạn T sau mổ.

Tư khóa: Ung thư khoang miệng, di căn hạch cồ.

\section{SUMMARY}

EVALUATION OF CERVICAL LYMPH NODES METASTASIS AND ITS RELATIONSHIP WITH FEATURES OF ORAL CAVITY CANCER

Objective: To evaluate the rate of cervical lymph nodes metastasis and its relationship with characteristics of oral cavity cancer. Patients and method: Restrospective analysis of 158 patients with CT1-4N0-2M0 oral cavity cancer were diagnosed and treated at K hospital from 2017 to 2019. Results: Median age was $56,1 \pm 10,1(25-83)$. The rate of male was $73,4 \%$. The proportion of cervical lymph nodes metastasis was $32,9 \%$ while the rate of patients with cNO was $21,5 \%$. There were significant

\section{Trường Đại học Y Hà Nội}

${ }^{2}$ Bênh viện $K$

Chiu trách nhiệm chính: Lê Văn Quảng

Email: lequang@hmu.edu.vn

Ngày nhận bài: 11.1.2021

Ngày phản biện khoa học: 2.3.2021

Ngày duyệt bài: 12.3.2021 relations between cervical lymph nodes metastasis and tumor size ( $p<0,001, \mathrm{CI} 95 \% 2,3-9,5)$, DOI $(p<0,001 ; C I 95 \% 2,7-14,9)$ và $p T$ stage $(p<0,001)$. respectively. Conclusion: Cervical lymph nodes metastasis was associated with tumor size, DOI and posoperative T stage.

Keywords: Oral cavity cancer, cervical lymph nodes metastasis.

\section{I. ĐẶT VẤN ĐỀ}

Ung thư khoang miệng (UTKM) là một trong những bệnh phổ biến, chiếm khoảng 30 - 40\% các ung thư của vùng đâu cô. Theo GLOBOCAN 2020, hằng năm có khoảng 377.713 ca mới mắc và 177.757 ca ca tử vong do ung thư khoang miệng [1]. Điều trị UTKM là điều trị đa mô thức, đòi hỏi sự phối hợp của nhiều chuyên khoa khác nhau trong đó phâuu thuât có vai trò quan trọng nhất. Xạ trị, hoá chất thường có vai trò bổ trợ.

Di căn hạch cổ là yếu tố tiên lượng quan trong của ung thư khoang miêng. Hiên nay các nghiên cứu về ung thư khoang miêng nói chung và tình trạng di căn hạch cổ tại Việt Nam còn hạn chế, do đó chúng tôi thực hiện đề tài: "Đánh giá tình trang di căn hạch cồ và mối liên quan tới đặc điểm bệnh học ung thư khoang miệng"

\section{II. ĐỐI TƯợNG VÀ PHƯƠNG PHÁP NGHIÊN CỨU}

2.1. Đối tượng nghiên cứu. Gồm 158 BN chẩn đoán ung thư khoang miệng giai đoạn cT14N0-2M0 điều tri tai bệnh viên K từ 2017 - 2019.

\section{- Tiêu chuẩn Iứa chọn BN}

+Chẩn đoán ung thư khoang miệng giai đoạn $\mathrm{CT} 1-4 \mathrm{n} 0-2 \mathrm{m0}$

+Được phẫu thuật cắt lưỡi bán phân và vét hạch cổ, điêu trị xạ trị hoặc hóa xạ trị bổ trợ nếu có.

+Mô bệnh học sau mổ: ung thư biểu mô vảy. 
+Thể trạng chung tốt: ps từ 0-1

-Tiêu chuân loai trừ :

+Hồ sơ lưu trữ không đầy đủ.

+Bệnh nhân có các bệnh mạn tính hoặc cấp tính trầm trọng có khả năng gầy tử vong trong thời gian ngắn.

2.2. Phương pháp nghiên cứu: Mô tả hồi cứu.

III. KẾT QUẢ NGHIÊN CỨU VÀ BÀN LUẬN

3.1. Đặc điểm lâm sàng, cận lâm sàng

Bảng 1: Đăc điểm bếnh hoc ung thu khoang miệng

\begin{tabular}{|c|c|c|}
\hline Đặc điểm & $\begin{array}{l}\text { Kết } \\
\text { quả }\end{array}$ & $\begin{array}{c}\text { Tỷ lệ phần } \\
\text { trăm }\end{array}$ \\
\hline Tuổi bệnh nhân (tuổi) & \multicolumn{2}{|c|}{$\begin{array}{c}56,1 \pm 10,1 \\
(25-83)\end{array}$} \\
\hline \multicolumn{3}{|l|}{ Giới (n) } \\
\hline Nam & 116 & $73,4 \%$ \\
\hline Nũ̃ & 42 & $26,6 \%$ \\
\hline \multicolumn{3}{|c|}{ Vị trí u (n) } \\
\hline Lưỡi di động & 96 & $60,8 \%$ \\
\hline Sàn miệng & 49 & $31,0 \%$ \\
\hline Niêm mạc má & 5 & $3,2 \%$ \\
\hline Lợi hàm dưới & 3 & $1,9 \%$ \\
\hline Lợi hàm trên & 1 & $0,6 \%$ \\
\hline Môi & 3 & $1,9 \%$ \\
\hline Khe liên hàm & 1 & $0,6 \%$ \\
\hline \multicolumn{3}{|c|}{ Giải phâu bệnh (n) } \\
\hline Ung thư biếu mô vảy & 158 & $100 \%$ \\
\hline \multicolumn{3}{|c|}{ Giai đoạn trước phâu thuật } \\
\hline cNO & 135 & $85,4 \%$ \\
\hline cN1 & 19 & $12,0 \%$ \\
\hline $\mathrm{cN2}$ & 4 & $2,5 \%$ \\
\hline \multicolumn{3}{|c|}{ Phương pháp phâu thuật (n) } \\
\hline Cắt rộng u + VHC & 158 & $100 \%$ \\
\hline $\begin{array}{l}\text { Cắt xương hàm dưới đứt } \\
\text { đoạn }\end{array}$ & 7 & $4,4 \%$ \\
\hline $\begin{array}{l}\text { Cắt xương hàm dưới không } \\
\text { đứt đoạn }\end{array}$ & 4 & $2,5 \%$ \\
\hline Cắt xương hàm trên & 1 & $0,6 \%$ \\
\hline \multicolumn{3}{|c|}{ Tạo hình lại khuyết hống khoang miệng } \\
\hline Không tạo hình & 107 & $67,7 \%$ \\
\hline Vạt dưới cằm & 26 & $16,5 \%$ \\
\hline Vạt lưỡi & 13 & $8,2 \%$ \\
\hline Vạt rãnh mũi má & 9 & $5,7 \%$ \\
\hline Vạt vi phâu đùi trước ngoài & 3 & $1,9 \%$ \\
\hline
\end{tabular}

Tuối và giới. Trong nghiên cứu của chúng tôi, tuổi trung bình là 56,1 $\pm 10,1$ (25 - 83). Nam chiếm đa số $(73,4 \%)$. Kết quả của chúng tôi cũng tương tự các tác giả khác trong và ngoài nước. Theo Ngô Xuân Quý và cộng sự 2019, tuổi trung bình là $52,5 \pm 8,6$ tuổi; nam giới là chủ yếu[2]. Theo Zanoni và cộng sự (2019), khi nghiên cứu 2.082 bênh nhân ung thư lưỡi tại Mỹ cho thấy tuổi mắc bệnh trung bình là 62 tuổi, trong đó có $55 \%$ số bệnh nhân trên 60 tuổi và đa phần là nam giới [3]. Nam hay gặp hơn nữ giới là do nam giới chịu ảnh hưởng của nhiều yếu tố nguy cơ như hút thuốc lá, uống rượu...

Đặc điểm bệnh học và phẫu thuật bệnh nhân UTKM. Trong số 158 bệnh nhân UTKM, vị trí hay gặp là lưỡi di động và sàn miệng, chiếm lần lượt là $60,8 \%$ và $31,0 \%$. Các vị trí khác như niêm mạc má, lợi hàm, khe liên hàm ít gặp hơn. Ngoài ra có 135 bệnh nhân chưa phát hiện di căn hạch trên lâm sàng và các phương tiện chẩn đoán hình ảnh được phẫu thuâtt vét hạch cổ chọn lọc dự phòng; còn lại 23 bệnh nhân $\mathrm{cN1} 1,2$ có chỉ định vét hạch cồ điều trị. Có 51 bệnh nhân tạo hình lại khuyết hổng sau phấu thuật, trong đó có 3 ca vi phẫu tạo hình lại khuyết hổng bằng vạt đùi trước ngoài do khuyết hổng lớn, phức tạp sau phẫu thuật.

Tình trạng di căn hạch cổ. Đa số bệnh nhân ở giai đoạn pT1,2 sau phẫu thuật, pT3 chiếm $13,9 \%$, pT4a chiếm $5,7 \%$. Tất cả bệnh nhân đều được vét hạch cổ, số lượng hạch trung bình vét được là 12,8 hach (7-34 hach). Tỷ lê di căn hach sau mổ là $32,9 \%$, trong đó di căn hạch tiềm ẩn là $21,5 \%$. Mức độ xâm lấn sâu trung bình là $7,6 \mathrm{~mm}$, trong đó $\mathrm{DOI}>5 \mathrm{~mm}$ chiếm $58,9 \%$. Tỷ lê di căn hach tiềm ẩn trong nghiên cứu của chúng tôi thấp hơn các tác giả trong nước. Tỷ lệ di căn hạch tiềm ẩn theo Nguyễn Đức Lợi, Nguyễn Đức Huân, Vũ Trung Chính lần lượt $23,7 \% ; 29,6 \%$ và $33,3 \%$ [4],[5],[6]. Điều này có thể giải thích là do nhóm bệnh nhân của chúng tôi bao gồm cả nhóm bệnh nhân lưỡi di động, sàn miệng, niêm mạc má, lợi hàm trên ; khi đó tỷ lê di căn hach thường sẽ thấp hơn do một số vị trí thường ít di căn hạch hơn các vị trí còn lại như niêm mạc má, lợi hàm trên...

Bảng 2: Đặc điểm bệnh nhân UTKM sau mổ

\begin{tabular}{|c|c|c|}
\hline Đặc điểm & $\begin{array}{c}\text { Kết } \\
\text { quả }\end{array}$ & $\begin{array}{c}\text { Tỷ lệ phần } \\
\text { trăm }\end{array}$ \\
\hline \multicolumn{3}{|c|}{ Giai đoạn T sau mố } \\
\hline PT1 & 60 & $38,0 \%$ \\
\hline PT2 & 67 & $42,4 \%$ \\
\hline PT3 & 22 & $13,9 \%$ \\
\hline pT4a & 9 & $5,7 \%$ \\
\hline
\end{tabular}

Số lượng hạch vét được $12,8 \pm 6,3(7-34)$ Giai đoan $\mathbf{N}$ sau mố

\begin{tabular}{|c|c|c|}
\hline pN0 & 106 & $67,1 \%$ \\
\hline pN1 & 31 & $19,6 \%$ \\
\hline pN2a & 10 & $6,3 \%$ \\
\hline pN2b & 9 & $5,7 \%$ \\
\hline pN2c & 2 & $1,3 \%$ \\
\hline pN3 & 0 & 0 \\
\hline
\end{tabular}




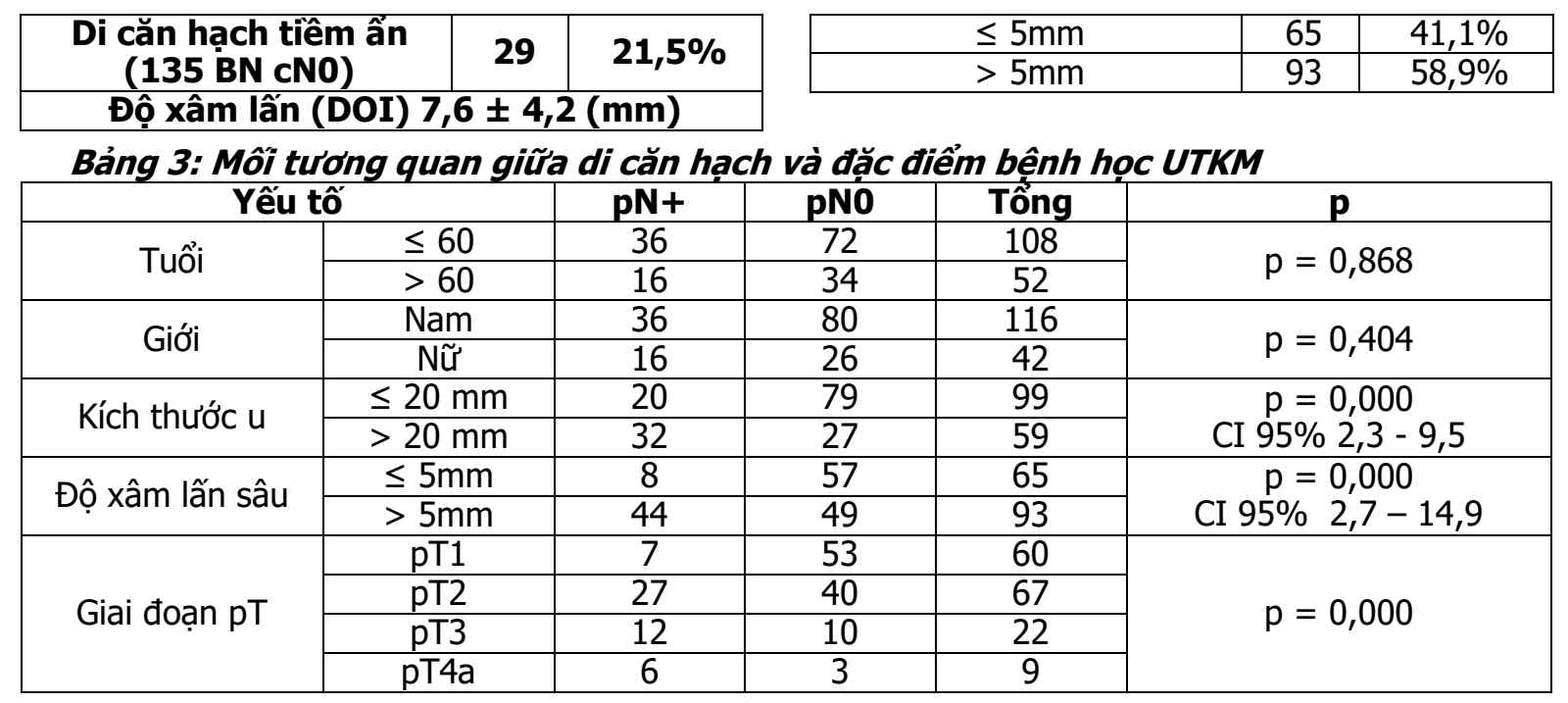

Môii tương quan giữa di căn hạch cổ và đặc điểm bệnh học ung thư khoang miệng

Kết quả của chúng tôi cho thấy không có mối tương quan giữa tình trạng di căn hạch với tuổi và giới $(p>0,05)$. Kết quả này cũng tương tự với các tác giả trong nước và quốc tế. Kết quả này cũng tương tự với nghiên cứu của các tác giả Vũ Trung Chính, Nguyễn Đức Huân, Cho Jung-Hae, Alessandro. Trong nghiên cứu của Nguyễn Đức Huân, nhóm tuổi $>50$ tuổi có tỷ lệ di căn hạch là $35 \%$ và nhóm <50 tuổi có tỷ lệ di căn hạch khoảng 14\%, không khác biệt với $p=0,3$. Nghiên cứu của tác giả Cho Jung-Hae cho thấy khác biệt không ý nghĩa thống kê giữa tỷ lệ di căn hạch trong nhóm $<60$ tuổi và $\geq 60$ tuổi với $p=0,122$ [7]. Nghiên cứu của Alessandro cũng cho kết quả tương tự, không khác biệt tỷ lệ di căn hạch giữa các nhóm tuổi, $p=0,24$ [8].

Tác giả Nguyễn Đức Huân cho thây tỳ lệ di căn hạch ở nam giới cao hơn nữ giới (40\% so với $16,7 \%$ ), nhưng khác biệt không có ý nghĩa thống kê với $p=0,18$. Tác giả Cho Jung-Hae cũng ghi nhận không khác biệt giữa 2 nhóm giới tính với $p=1,0$ [7]. Trong nghiên cứu của Alessandro thì tỷ lệ di căn hạch ở nam là $25,7 \%$ và tỷ lệ di căn hạch ở giới nữ là $20 \%$, không khác biệt với $\mathrm{p}>0,05$ [8]. Nghiên cứu của tác giả Chaudhary cũng cho kết quả tương tự [9].

Kết quả của chúng tôi cho thấy, tình trạng di căn hạch có mối tương quan chặt chẽ với kích thước u ( $p<0,001, C I 95 \% 2,3-9,5)$, độ xâm lấn sâu $(p<0,001 ; C I 95 \% 2,7-14,9)$ và giai đoạn T sau mổ $(p<0,001)$. Kết quả này tương tự với Nguyễn Văn Tài (2018) cho thây trường hợp DOI $>5 \mathrm{~mm}$ có tỷ lệ di căn hạch tiềm ẩn cao hợn nhóm $\mathrm{DOI} \leq 5 \mathrm{~mm}$, khác biệt có ý nghĩa thống kê với $p=0,032$. Tác giả Nguyễn Đức Huân cho thấy tỷ lệ di căn hạch trong nhóm bệnh nhân có DOI $>5 \mathrm{~mm}$ là $43,8 \%$; trong khi tỷ lệ này trong nhóm $\mathrm{DOI} \leq 5 \mathrm{~mm}$ chỉ $9,1 \%$; khác biệt có ý nghĩa thống kê với $p=0,04$. Trong nghiên cứu của Vũ Trung Chính, tỷ lệ di căn hạch có khác biệt có ý nghĩa thống kê khi so sánh độ sâu xâm nhập với $p=0,048$. Trong nghiên cứu của tác giả Cho Jung-Hae cũng cho thấy sự khác biệt có ý nghĩa thống kê giữa 2 nhóm này với $p<0,001$ [7]. Tác giả Alessandro thì lựa chọn DOI với ngưỡng $7 \mathrm{~mm}$, trong đó tỷ lệ di căn hạch của nhóm có DOI> $7 \mathrm{~mm}$ là $37,5 \%$; trong khi chỉ $7,1 \%$ di căn hạch trong nhóm $\mathrm{DOI}<7 \mathrm{~mm}$, khác biệt có ý nghĩa thống kê với $p=0,043[8]$. Tương tự, nghiên cứu của tác giả Ahmed cho thây có tới $69 \%$ bệnh nhân DOI > $5 \mathrm{~mm}$ có di căn hạch, trong khi $100 \%$ bệnh nhân DOI $\leq 5 \mathrm{~mm}$ không di căn hạch, $p<0,0001$.

Ngoài ra, các nghiên cứu trên thế giới cũng đề cập đến một vài yếu tố khác cũng ảnh hưởng đến tình trạng di căn hạch tiềm ẩn trong UTL giai đoạn sớm như xâm lấn thần kinh ngoại vi, mạch bạch huyết. Trong nghiên cứu của tác giả Alessandro, đối với bệnh nhân có xâm nhập mạch bạch huyết và xâm lấn thần kinh ngoại vi trển mô bệnh học thì tỷ lệ di căn hạch tiềm ẩn cao hơn, khác biệt có ý nghĩa thống kê với $\mathrm{p}<0,05$. Tỷ lệ di căn hạch khi so sánh với yếu tố xâm lấn bạch mạch với phân tích đa biến có $\mathrm{p}=0,002$; tỷ lệ di căn hạch trong nhóm xâm lấn thần kinh ngoại vi là 37,5\% trong khi chỉ 6,3\% di căn hạch trong nhóm không xâm lấn, khác biệt với $p=0,032$ [8]. Tuy nhiên, tác giả Cho JungHae ghi nhận không có sự liên quan giữa tình 
trạng xâm lấn bạch mạch và di căn hạch với $p>0,05$ [7].

\section{KẾT LUÂAN}

Tỷ lê di căn hach sau mổ là 32,9\%, trong đó di căn hạch tiềm ẩn là $21,5 \%$. Tình trạng di căn hạch cổ có mối tương quan chặt chẽ với kích thước u, độ xâm lấn sâu và giai đoạn T sau mổ.

\section{TÀI LIÊU THAM KHẢO}

1. Sung $H$, Ferlay J, Siegel $R L$, Laversanne $M$, Soerjomataram I, Jemal A, Bray F. Global cancer statistics 2020: GLOBOCAN estimates of incidence and mortality worldwide for 36 cancers in 185 countries. CA Cancer J Clin. 2021 Feb 4. doi: 10.3322/caac.21660. Epub ahead of print. PMID: 33538338.

2. Ngô Xuân Quý (2019). Nghiên cứu kết quả hóa tri bổ trớ trước phác đồ TC và tỷ lể bốc lộ môt số dấu ấn liên quan đến ung thư lưới giai đoạn III- IV (M0), Trường Đại học Y Hà Nội, Hà Nội.

3. Zanoni DK, Montero PH, Migliacci JC, et al (2019). Survival outcomes after treatment of cancer of the oral cavity (1985-2015). Oral Oncol, 2019. 90: 115-121
4. Nguyễn Đứrc Lợi (2002), Nghiên cứu đặc điểm lâm sàng và một số yếu tố tiên lương bềnh ung thư lưỡi điều trị tại bệnh viện $K$, Trường Đại học Y Hà Nội, Hà Nội.

5. Nguyến Đức Huân (2012), Đánh giá tình trạng di căn hạch cổ trong ung thư lưỡi giai đoạn sớm tại bênh viên $\mathrm{K}$ năm 2012, tap chí $Y$ hoc Viêt Nam, số 1 .

6. Vũ̃ Trung Chính (2014), Nghiên cứu đặc điểm lâm sàng, mô bệnh học và tình trạng di cằn hạch cổ trong ung thư lưỡi di đông giai đoan sớm $(T 1, T 2)$ tại Bệnh viện $K$, Trướng Đại học y Hà Nội, Hà Nội.

7. Cho Jung-Hae, Lee Youn-Soo, Sun Dong-Il và công sứ (2016). Prognostic impact of lymph node micrometastasis in oral and oropharyngeal squamous cell carcinomas. Head \& Neck, 38 (S1), E1777-E1782.

8. André Fernandes d'Alessandro, Fábio Roberto Pinto, Chin Shien Lin và cộng sự (2015). Oral cavity squamous cell carcinoma: factors related to occult lymph node metastasis. Brazilian Journal of Otorhinolaryngology, 81, 248-254.

9. Neena Chaudhary, Rajeev Verma, Usha Agarwal và công sứ (2017). Incidence of occult metastasis in clinically NO oral tongue squamous cell carcinoma and its association with tumor staging, thickness, and differentiation. Journal of Head \& Neck Physicians and Surgeons, 5 (2), 75-78.

\section{TÌNH TRANG DINH DƯÕ̃NG TRƯỚC PHẪU THUÂT Ở BÊNH NHÂN UNG THƯ ĐAI TRỨC TRÀNG TẠI BỆNH VIÊ̂N ĐẠI HỌC Y DƯỢC THÀNH PHỐ HỒ CHÍ MINH}

Đoàn Duy Tân*, Võ Duy Long**, Lê Thị Hương***

\section{TÓM TẮT}

Đắt vấn đề: Ung thư đại trực tràng (UTĐTT) là một trong những loại ung thư (UT) phổ biến nhất trên thế giới. Theo GLOCOBAN 2018 UTĐTT xếp thứ 3 về tỉ lệ mắc $(10,2 \%$ với $1.849 .518 \mathrm{ca})$ và xếp thứ 2 về tỉ lệ tử vong (9,2\% với $880.792 \mathrm{ca})$. UT đường tiêu hoá đã் được chứng minh có tỉ lệ SDD cao hơn so với các vị trí khác chiếm $20-85 \%$, trong đó $28-52,4 \%$ bênh nhân UTĐTT được chẩn đoán SDD. SDD trước và sau mổ có thể tác động đến quyết định phương pháp điều tri, ảnh hưởng đến hệ miễn dịch của cỡ thể gây tăng nguy cơ biến chứng sau mồ như nhiễm trùng hoăc xì rò vết mổ $(5-52 \%)$, giảm đáp ứng và tăng chi phí điều tri (hơn $25 \%$ ), kéo dài thời gian nằm viên $(8-60$ ngày) tăng gấp đôi nếu có SDD nặng chu phâuu, tăng

*Đại hoc Y Dược Thành phố Hồ Chí Minh

**Bênh viên Đai hoc Y Dước TP. HCM; Đại hoc Y Dước Thành phố Hồ Chí Minh

***Viện đào tạo Y học dự phòng và Y tế Công cộng, Đai hoc Y Hà Nôi.

Chịu trách nhiệm chính: Đoàn Duy Tân

Email: doanduytaan@ump.edu.vn

Ngày nhâan bài: 5.01 .2021

Ngày phản biên khoa hoc: 1.3.2021

Ngày duyệt bài: 10.3.2021 tỉ lệ tử vong, từ đó làm suy giảm chất lượng cuộc sống, đáp ứng điều trị và tiên lượng bệnh. Mục tiêu: Xác định tỉ lệ suy dinh dưỡng trước phẫu thuật của bệnh nhân ung thư đại trực tràng tại bênh viện Đại học $Y$ Dược Thành phố Hồ Chí Minh. Đối tượng và phương pháp nghiên cứu: Nghiên cứu cắt ngang mô tả được tiến hành trên 130 bệnh nhân ung thư đại trực tràng tai bệnh viện Đai họ Y Dược Thành phố Hồ Chí Minh từ 10/2020 - 02/2021. Thông tin được thu thâp bằng bô câu hỏi soan sẵn, qua phỏng vấn và khám trực tiếp mặt đối mặt và tra cứu hồ sơ bệnh án. Kết quả: Tỉ lê suy dinh dưỡng trước phẫu thuật theo PG-SGA: $52,3 \%$, trong đó SDD mức độ nặng chiếm $16,9 \%$, tình trang theo $\mathrm{BMI}$ và albumin lần lượt là: $13,1 \%, 38,5 \%$. Có sự khác biệt có ý nghĩa thống kê giữa cân năng trước nhâp viên 6 tháng và cân năng khi nhập viện $(p<0,001)$. Kết luận: Đánh giá dinh dưỡng toàn diên cho bênh nhân ung thư đai trực tràng trước khi phẫu thuật nên được thực hiện để can thiệp dinh dưỡng kịp thời, thích hợp và tăng đáp ứng và hiêu quả điều trị.

Ti̛ khoá: suy dinh dưỡng, ung thư đại trực tràng, PG-SGA

\section{SUMMARY \\ PRE-OPERATIVE NUTRITIONAL CONDITION IN COLORECTAL CANCER}

